\title{
Transgressive Technologies?
}

Strategies of Discursive Containment in the Representation and Regulation of Assisted Reproductive Technologies in Aotearoa/New Zealand

\author{
Dr Carolyn Michelle \\ Convenor, Women's and Gender Studies Programme \\ Department of Societies and Cultures \\ University of Waikato \\ Private Bag 3105 \\ Hamilton \\ Aotearoa/New Zealand \\ Ph: +64 078384847 \\ Fax: +64 078384654 \\ Email: caro@waikato.ac.nz
}

Short Title: Transgressive Technologies?

Acknowledgements:

This project was funded by a grant from the Faculty of Arts and Social Sciences at the University of Waikato, and carried out with the help of two research assistants, Jennifer Germon, and Natalie Cowley. 


\title{
Transgressive Technologies?
}

\section{Strategies of Discursive Containment in the Representation and Regulation of Assisted Reproductive Technologies in Aotearoa/New Zealand}

\begin{abstract}
:
Drawing on a case study of the contemporary representation and regulation of assisted reproductive technologies in Aotearoa/New Zealand, this paper traces the cultural anxieties evident in public, political, and media discussion and debate around the provision and use of ART, with a specific focus on the use of donor insemination and IVF by single women and lesbian couples. It documents the operation of various narrative mechanisms, normative assumptions, and discursive strategies that work to identify the legitimate uses and users of such technologies whilst simultaneously affirming conventional understandings of "gender", "motherhood", and "the family", and concludes that contemporary anxieties and ethical dilemmas provoked by women's transgressive uses of ART have been addressed through legislative changes that target these women for official surveillance and control while also effectively limiting their reproductive options.
\end{abstract}




\section{Biographical Statement:}

Carolyn Michelle convenes the Women's and Gender Studies programme at the University of Waikato, and lectures in the Department of Societies and Cultures. Her previous research has been in the areas of gender and media, and documentary representations of domestic violence (with C. Kay Weaver). 


\section{Transgressive Technologies?}

\section{Strategies of Discursive Containment in the Representation and Regulation of Assisted Reproductive Technologies in Aotearoa/New Zealand}

\section{Introduction}

The birth of the world's first "test tube", baby in 1978 sparked extensive public debate about the social and ethical implications of in vitro fertilisation (IVF) and related human assisted reproductive technologies (ARTs), including gamete donation. This debate has been especially intense (and divisive) among feminists, both within and outside academia. Early feminist discussions were predominantly very critical, with radical feminists denouncing ARTs as modes of patriarchal and medicalised violence designed to control, exploit and eventually appropriate women's reproductive capacity. FINRRAGE (1985), for example, described IVF as allowing the "take-over of our bodies for male use, for profit making, population control, medical experimentation and misogynist science" (as cited in Sawicki, 1991, p. 77), while Gena Corea (1985) argued that women's bodies are being reduced to objects through the use of (frequently unsuccessful) technologies that fragment, degrade, and commodify motherhood. In the process, women's bodies and lives become increasingly surveyed, controlled and regulated by male "technodocs" in concert with other legal and state agencies. Corea further warned of the potential for gynocide, claiming that the ultimate goal of reproductive science is to entirely externalise reproduction through the use of gamete donation, IVF, embryo transfer, artificial wombs ("mother machines"), and cloning technologies, eventually eliminating the need for real women (see also Klein, 1991; Raymond, 1993).

While critiques in this vein continue to be voiced, a growing body of feminist work on this topic has been informed by the post-modern theoretical turn (see for example Franklin, 1990; 
Sawicki, 1991; Farquhar, 1996; Shildrick, 1997). These discussions typically acknowledge that whilst patriarchal political interests have certainly shaped the development of ART, these technologies are not the products of monolithic structures. Hence, different procreative technologies and practices can have diverse implications and consequences for different groups of women, depending on the wider cultural and economic contexts of their regulation and use (Balsamo, 1996). Post-modern feminists further emphasise the disruptive and transformative potential of certain uses of ART (while not discounting the risks, failures, and emotional and financial costs that may be involved in more 'high-tech' procedures), arguing that by severing the link between heterosexual sex and biological reproduction, certain uses of ART make it possible to subvert, fragment, transform and re-inscribe conventional meanings of "nature", "gender", "reproduction", "motherhood", and "the family" in potentially radical and transgressive ways (Franklin, 1990; Farquhar, 1996). That is to say, the capacity for reproduction to transcend individual bodies via ART--while abhorrent to many radical feminists--makes “different performances or 'experiences' of maternity and family possible" (Farquhar, 1996, p.6). Increasingly, the achievement of biological parenthood is not limited by one's age, marital status, sexual orientation, or 'natural' fecundity, and it is this transcendence of the body through technical means that has renewed cultural negotiations around who can become a mother, and under what circumstances. Similarly, conventionally exclusive definitions of the 'family' as properly patriarchal, heterosexual and nuclear are disrupted where ART is used to facilitate the creation of nontraditional family forms.

As noted by Farquhar (1996), the use of ART by single women and lesbians in particular -most often in the form of low-tech procedures such as DI or self insemination but in some cases IVF, and potentially haploidisation if recent claims are to be believed ${ }^{\mathrm{ii}}$--clearly poses a challenge to patriarchal reproductive hegemony, as many legislators and social commentators have decried. In the contemporary context, what appears most at stake in the continued 
development of ART is "the necessity for the social and cultural reproduction of specific definitions of parenthood and procreation, of traditional family values and of conventional sexual arrangements" (Franklin, 1990, p. 226). Increasingly, conventional sexual relations and related family structures are no longer necessary for reproduction, heralding a new biological "reality" that generates considerable cultural anxiety.

In this paper, I suggest that in the contemporary context of Aotearoa/New Zealand, such anxiety seems primarily focused, not on the technological appropriation of women's reproductive capacity (as feared by radical feminists), but rather, on the increasingly tenuous relationship between men and reproduction, and on perceived threats to an historically privileged family form. Thus, much recent public, political, and media discussion of ART reflects a growing realisation and corresponding unease that fathers and the traditional nuclear family might now be inessential, and that, given the opportunity, significant numbers of women might actively choose to reproduce through alternative means. Admittedly, such fears were expressed in the immediate wake of Louise Brown's birth, and re-emerged here in the mid-1990s following successful legal challenges to clinic policies that excluded single women and lesbian couples from receiving donor gametes (New Zealand Ministerial Committee on Assisted Reproductive Technologies, 1994; New Zealand Listener, 1995). Public and political anxiety regarding the immanent "redundancy" of men and the traditional family unit may also have been fuelled by oft-repeated remarks by the Member of Parliament responsible for introducing the Human Assisted Reproductive Technology Bill, who remarked in her 1996 introductory speech that "New Zealand needs only eight virile men with strong sperm counts to maintain the population and gene pool of New Zealand". Her comments sparked alarm among certain male colleagues, while one or two others apparently clambered to serve as one of the "lucky" eight (Yates, 2001). 
Of particular interest in this paper, then, is the implicit and at times explicit influence of such anxieties within local discussions of ART and of the proposed legislation; discussions which I suggest work to discursively contain the transgressive potential of certain uses of ART whilst simultaneously reasserting the social, psychological, and legal necessity of fathers. At the centre of this ongoing process of discursive, political and legal contestation are the single and/or lesbian mothers who actively choose to reproduce without direct heterosexual contact and outside the patriarchal heterosexual family structure - a situation that appears especially subversive and threatening to patriarchal reproductive hegemony, since it "both decisively rejects normative biological reproduction, and situates a desire which threatens to leak out into the very centre of the phallocratic order" (Shildrick, 1997, p.189).

The following discussion thus traces some of the cultural anxieties evident in public, political, and media discussion and debate around the provision and use of ART in Aotearoa/New Zealand, with a specific focus on representations of single and lesbian motherhood made possible through sperm donation. Drawing on a sample of magazine and newspaper texts, ${ }^{\mathrm{iii}}$ transcripts of parliamentary debates, past and current legislation, official policy documents, and interviews with fertility specialists and counsellors, this paper identifies various narrative mechanisms, discursive assumptions and representational strategies that operate to contain contemporary anxieties by defining and delimiting the legitimate uses and users of such technologies, whilst simultaneously affirming conventional gender performances and reproducing hegemonic meanings of "nature", "gender", "reproduction", "motherhood", and "family". It illustrates that the potential of certain uses of ART to transgress and re-inscribe these conventional meanings is determined, not by the technologies themselves, but by various implicit and explicit constraints placed on their use within the broader social, political, medical, legal, and representational realms, which can and do change over time. It also highlights some of the potential consequences of these 
constraints for those unable or unwilling to conform to heteronormative family ideals and their offspring.

In adopting such a focus, I wish to momentarily set aside questions regarding whether anyone should have access to assisted reproductive technologies given the physical, emotional, and financial costs and risks potentially involved (particularly in the case of more 'high-tech' procedures), and social and global inequities in the allocation of limited health resources. In setting aside these questions, I do not discount their relevance or importance. Rather, I take the pragmatic view that, for good or for ill, ART is now an established and widely used means of resolving involuntary childlessness in many wealthy pro-natalist countries, and increasingly also among an emerging middle-class within certain developing nations. This situation seems unlikely to change. Further, in Aotearoa/New Zealand at least, the public provision of fertility services has become a highly politicised issue, with increasingly vocal demands on the state to fund fertility treatment--but only for some. In such a charged political context, it seems timely to consider the basis upon which any publicly funded treatment is offered, and to whom, and to consider the various inclusions and exclusions that stem from past and current policy and practice.

It is also important to acknowledge that the technologies themselves vary markedly in terms of the degree of medical intervention involved. While no local research currently exists on this issue, anecdotal evidence suggests it is likely that the majority of single women and lesbians utilise the unregulated 'low-tech' option of self insemination of sperm provided by a friend or acquaintance. However, it is clear from the self-reporting of fertility clinics that a growing number of these women are actively seeking their services because they can't find a willing donor, prefer to use sperm that has been screened for infectious diseases, and/or view the use of a fertility clinic as a safer option medically, legally and emotionally, since there is no question of the donor seeking an ongoing relationship with the child. As in the general 
population, a significant number of single women and lesbians are likely to be sub-fertile (in the case of single women, this is often age-related, as the decision to parent alone is typically made after several years of unsuccessfully trying to find a suitable partner or donor), which may lead to the use of drugs to stimulate ovulation, and in a small but growing number of cases, IVF. Since the desired outcome in these cases is the same (motherhood outside the traditional patriarchal family structure), I do not distinguish between the method of conception in the subsequent discussion. In all such cases, the use of donor sperm can be presumed, and this is the issue that has recently occupied public and political imaginations, not the degree of medical intervention undertaken. Thus, the analysis that follows largely addresses itself to wider debates over ends (the kinds of 'families' potentially produced via ART), rather than the means used to attain those ends (the technologies themselves).

\section{Mainstream Media And The Hyper-Visibilisation Of ART's Authorised Agents}

Underpinning this analysis is the view that at different moments, popular media representations can either provoke or appease contemporary anxieties about the increasingly complex realm of human reproduction (Farquhar, 1996). Such representations impart new knowledges about the potential capacities and benefits of ART, and at times actively solicit readers' and viewers' identifications with those who provide, use, or are impeded in using these technologies (Ibid.). As such, media representations play an important role in framing public, private and political understandings of the uses, users, and possible social, legal and ethical implications of ART. Thus, while these technologies theoretically have the potential to redefine who can become a mother and under what circumstances, some circumstances are rendered more visible, possible, and indeed more desirable than others within media content and public policy.

In terms of local media representations, audience identifications are actively recruited via a predominant narrative strategy of "anecdotal personalisation” (Nisbet, Brossard, \& Kroepsch, 
2003, p. 48), usually in the form of "real life" human interest stories featuring the struggles, triumphs and personal testimonies of women and couples who have used, or been somehow impeded in using, assisted reproductive technologies to achieve a desired end; most commonly a "take-home baby" of their own. Thus, the potential benefits and implications of ART are frequently introduced and explored using the experiences and viewpoints of individuals, couples, and fertility specialists as the primary frame of reference. As noted by Ann Karpf (1988) and Alan Petersen (2001), this narrative mode is a common journalistic technique used to create interest and make "high-tech" procedures and technologies more relevant and personally meaningful to lay audiences, by demonstrating their value for particular individuals and couples. The resulting personal stories are often emotionally compelling and highly readable, inviting readers to identify with characters and share in their personal struggles and triumphs (Franklin, 1990).

However, it is highly significant that only certain kinds of subjects and situations are offered to readers to identify with. Around 95 percent of those depicted as users of fertility services are explicitly described as in a married, heterosexual relationship. Thus, local media hypervisiblises these subjects as the "proper" agents of ART whilst simultaneously marginalising those groups who do not fit this normative ideal: in particular, those in de facto couples, single women, lesbian couples, and gay men. For example, the firsthand views of single women and lesbians as mothers are only briefly related in just two out of 170 print media reports surveyed (McLean, 2002; Managh, 2004a)--including a large number of stories specifically relating to the issue of gamete donation and/or potential future treatments such as haploidisation--yet these groups now comprise around two thirds of donor sperm recipients at New Zealand's largest chain of fertility clinics, Fertility Associates (Managh, 2004b). While this figure might seem extraordinarily high, it can be largely attributed to the now commonplace use of intracytoplasmic sperm injection (ICSI) to treat male-factor infertility ${ }^{\text {iv }}$, 
with some local clinics claiming particular expertise in performing this technique and higher than average success rates (Dr Richard Fisher, as cited in Chisholm, 2002).

Similarly, involuntary childlessness is in all cases presumed to mean biological as opposed to social infertility (consistent with its medical definition), and is represented as the exclusive preserve of heterosexual couples. For example, one article states that "For most people, using donor insemination (DI) follows on from the discovery of male infertility" (Agnew, 2004, p.1); a misleading statement that reflects and preserves implicit hetero-normative presumptions whilst invisibilising many of those actually using DI. Similarly, recipients of sperm donation are presumed to be heterosexual couples: "The recipient couple are the legal parents and are named on the child's birth certificate" (Oliver, 2002, p.5). At the time, however, this only applied in the case of married and de facto heterosexual couples--lesbian partners were accorded no such recognition. Through these and other omissions and exclusions, local media coverage maintains and reinforces the image of the traditional patriarchal nuclear family in the face of threats arising from the increasingly diverse biological and social possibilities that flow from transgressive uses of ART (Franklin, 1990). Heterosexual and preferably married couples are identified as the authorised agents of these technologies, and "legitimate" uses are largely confined to the reproduction of the "ideal" nuclear family.

But while lesbians, single women, and gay men remain significantly underrepresented in the first-hand personalised accounts frequently related by local media, the fact that they can now use ART to create families that do not conform to the traditional ideal was certainly subject to intensive discussion and indeed critique, much of which served to further perpetuate the marginalisation and stigmatisation of non-traditional family forms. One article, for example, comprises a scathing attack on the use of anonymous sperm donation by lesbians and single women as a gross act of "maternal egoism" that is damaging to the child's emotional health: 
"Secrecy...is a smokescreen for selfishness--an opportunity for a parent to create a child in her own image. A certified blank slate. A creature unencumbered by heritage or past life baggage. A child without even a pesky mythical father to imagine" (Sumner-Burstyn, 2002, p.A17). Editorials also raised questions and concerns about the "fatherless families" produced with the help of ART:

[It] is the rights of the person or couples here and now that are being put ahead of the life of the person they want to conceive. Conception, which just a generation ago was possible only through natural, biological means is, through technology, available to any single woman or permutation of coupledom... [I]t may be years before it can be said with certainty that the arrangements have also worked for the children. Most people who became single parents did not set out to raise children alone. But increasingly, that is a choice for single women, even those who will never have had any intimate relationship with their child's father, and even though research shows that children are best off when they live in two-parent families. (The Dominion Post, 2004, p.4)

Such views appear to reflect a broader displacement of cultural anxieties away from the "unnaturalness" of artificial techno-reproduction and onto the "unnatural" and "undesirable" mothers and families these technologies potentially create. Hence, DI and IVF, once considered "unnatural", are now normalised as routine methods of assisting nature--a "natural" means of reproduction (Paxson, 2003)--but only within the context of the heterosexual, patriarchal nuclear family. As noted by Valerie Hartouni (1997), since their development, ARTs have become "assimilated into the order of nature or brought into the service of precisely those institutions, relations, and relationships or ways of life they seemed destined to raze, their transgressive potential at least temporarily contained" (p. 114). In effect, the boundaries between "natural" and "unnatural" reproduction have been redrawn in a way that focuses on ends as opposed to means, and thus emphasises, not the artificiality of the technology used, but rather the "legitimacy" of the families produced by them as judged in relation to dominant social norms and values. New demarcations are thus established 
between "good", legitimate, and "natural" assisted reproduction--that which allows heterosexual couples to reproduce and upholds familial ideals--and "bad", dangerous, illegitimate and "unnatural" reproduction--all that which occurs outside hetero-normative frameworks, including the creation of un-partnered mothers and lesbian and gay families.

\section{Containing ART's Transgressive Potential: Explicit And Implicit Constraints}

In some contexts, this displacement and refocalisation has inspired attempts to control and regulate fertility services in order to prevent the creation of "unnatural" or "pretended" families that might threaten the hegemony of the traditional family unit, most commonly by denying single women and lesbians access to fertility services. Such restrictions have been putatively justified on the basis of unfounded presumptions that "every child needs two parents living in the home; that every child needs a father living in the home; and that lesbians will detrimentally influence the gender or sexual identity of their children" (Walker, 2003, p. 128). Despite a lack of empirical evidence of such harm--and substantial evidence to the contrary ${ }^{\mathrm{v}}$--various countries now formally restrict access to DI and IVF to married couples or (in some cases) heterosexual couples in stable de facto relationships; including Austria, France, Denmark, Ireland and Sweden (Bryld, 2001; Pattinson, 2003). While at least half of U.K. fertility clinics now offer treatment to single women and lesbian couples, at the time of writing The Human Fertilisation and Embryology Act (1990) continues to states that "A woman shall not be provided with treatment services unless account has been taken of the welfare of any child who may be born as a result of the treatment (including the need of that child for a father)" (s.13(5)). In practice, this limits the use of ART to those who are willing and able to find a suitable man to act as a "father figure" to their child, on the basis of a common sense presumption of a need that is not necessarily borne out by research on the welfare of the child. 
Closer to home, the Australian government has expressed an intent to impose a nationwide ban on single women and lesbians accessing IVF services, with Prime Minister John Howard proposing in 2000 to amend the Federal Sex Discrimination Act to prevent it being used to challenge state laws denying single and lesbian women access to fertility treatment (Bennett, 2000). The state of Victoria originally imposed such a ban through The Infertility Treatment Act 1995, which stated that "a woman who undergoes a treatment procedure must be married" (s.8(1)), although a Federal Court later judged this provision to constitute unlawful discrimination on the grounds of marital status (Bennett, 2000; Szoke, 2003). Today, Victorian clinics continue to restrict access to those deemed medically infertile, in practice excluding the majority of single women and lesbians from any form of treatment (Cannold \& Gillam, 2003). A change of policy was introduced in 2004 allowing clinics to supply these groups with screened sperm for the purposes of self insemination, but was initially thought to expose recipients to another clause in the Infertility Treatment Act specifying that sperm insemination can only be carried out by a registered doctor or at a licensed hospital or clinic, with offenders facing a 4-year jail sentence or $\$ 48,000$ fine. This issue was very recently clarified after the Infertility Treatment Authority accepted legal advice that self insemination by women at home did not in fact breach the 1995 Act.

In Aotearoa/New Zealand, fertility services have been largely unregulated until recently, and there remains no legal impediment to self insemination. Initially, individual fertility service providers restricted access to heterosexual couples only--generally married, but in some cases also long-term de facto--on the grounds of generalised opposition to single women benefiting from their services, coupled with a presumption that the "child's best interests" were served by having parents who were in a committed heterosexual relationship (Daniels \& Burn, 1997). However, under the Human Rights Act 1993 it became illegal to discriminate in the provision of goods and services on the basis of disability, family status, or sexual orientation. Successful legal challenges subsequently established that public as well as private fertility 
clinics cannot lawfully deny single women, lesbians, and gay couples access to fertility treatment unless they hold serious concerns for the welfare of any resulting child ${ }^{\mathrm{vi}}$ (Ibid.). All is not quite as equitable as it seems, however, as eligibility criteria remain predicated on a hetero-normative presumption that effectively excludes the vast majority of these individuals from receiving publicly funded fertility treatment (Batty, 2002).

These eligibility requirements are outlined in the National Clinical Assessment Criteria (CPAC), which identifies eligible users as those unable to conceive after at least a year of unprotected intercourse, or those whose biological circumstances prevent attempting pregnancy or carrying one to term (Health Funding Authority, 2000). Having framed infertility in hetero-normative terms, lesbian couples and single women are thereby ineligible for any publicly funded treatment unless deemed biologically infertile, or "in the case of unexplained infertility to be confirmed by 12 cycles of DI of which 6 should be within an accredited RTAC unit" and carried out at their own expense (Health Funding Authority, 2000, p.6). A clear anomaly exists however, due to the fact that CPAC criteria treat heterosexual couples as one unit or patient. As noted by Kirejczyk (1994), the body being treated in ART is not necessarily the body that is actually infertile, and hence in the case of heterosexual couples, male factor infertility ${ }^{\mathrm{vii}}$ is considered grounds for publicly funded treatment of a healthy, biologically fertile female partner via DI or IVF with ICSI. In such cases, ART is clearly not being used to treat infertility as such. Rather, it is being used to resolve the couple's involuntary childlessness; the very same condition faced by many single women and lesbian couples. That is to say, the fertile female partner of an infertile man is socially rather than biologically infertile: She "could" in fact have children with a different male partner, just as most single women and lesbians "could" have children if willing and able to have intercourse with a fertile man (Kirejczyk, 1994). As Shildrick (1997) notes, single and lesbian women are "not so much excluded as made invisible within the terms of consideration" (p.185). Thus, CPAC guidelines implicitly restrict access to publicly funded 
ART treatment to those who most closely approximate conventional parental and familial norms, whilst marginalising and excluding certain other groups who fail to conform to dominant social ideals (Batty, 2002).

Historically, these same hetero-normative assumptions have been more overtly expressed in Aotearoa/New Zealand law, which effectively regulates who can constitute a family and defines the legal status of parties involved. Under the recently superseded 1968 Guardianship Act and 1987 Status of Children Amendment Act, women undergoing DI were presumed to be heterosexual and to have a consenting male husband or de facto partner able to "stand in the place of" the biological father under the pater est rule. Put simply, the man married to or cohabiting with the mother automatically became the legal father, while the sperm donor was deemed a "legal stranger" to the child and stripped of all rights and responsibilities. When lesbian couples conceived through DI, however, the woman who carried the child was recognised as the natural mother, whilst the female partner had no legal status, but could apply through the family court to become an additional guardian under the 1968 Guardianship Act. Since there was no other candidate for legal father in such cases, the sperm donor "technically" remained the legal father, but was generally not named on the birth certificate and was still relieved of any legal rights and responsibilities of paternity (Batty, 2002; Devereux, 2003). These inequities were recently addressed by the Care of Children Act 2004 and Status of Children Amendment Act 2004, which allow for the (consenting) same-sex partner of a mother using gamete donation to be listed as a legal parent on the birth certificate. It should be noted that adoption is not a legal option for gay and lesbian couples in Aotearoa/New Zealand, although they are deemed to make “acceptable" foster parents. Single persons, however, may adopt.

Thus it appears that to some extent, existing funding and eligibility criteria, outdated legislation, and government policy continue to impose a social and sexual hierarchy of 
families within both public and private domains by conferring greater legitimacy and authenticity on the traditional heterosexual nuclear family, whilst marginalising and legally disempowering those who wish to create alternative family forms (Cooper \& Herman, 1991). Given the current socio-political climate in Aotearoa/New Zealand, this situation seems likely to continue, despite recent progressive developments.

\section{“Truth" Of Origins: Genetic Essentialism And The Right To Know}

This context is clearly shaped by a growing conflation between human rights discourse and a predominant medico-scientific discourse, which together increasingly construct knowledge of genetic parentage as essential health information and a fundamental "right" (Kirkman, 2003). In terms of the former, the UN Convention on the Rights of the Child 1989 (to which Aotearoa/New Zealand is a signatory) formalised a growing concern with children's rights by stating that in all actions concerning children, including adoption, "the best interests of the child shall be the primary consideration" (Article 3(1)). Further, Article 8(1) outlines the state's responsibility to respect the child's right "to preserve his or her identity, including...family relations as recognised by law". While this convention makes no mention of gamete or embryo donation, many local commentators interpret these provisions as implying that all children have the right to know the identity of their genetic parents (Coney, 1999; Else, 1999; Daniels, 1995, 1998, 2004). Obligations to preserve and openly acknowledge genealogical links or "blood ties" are also seen to arise from the founding document of Aotearoa/New Zealand, the Treaty of Waitangi, in accordance with the Maori concept of whakapapa, defined as covering "not only the physical facts of genetic connection, but also the entire social history related to particular families and family members" (Else, 1999, p.57).

This rights-based affirmation of the need for openness regarding family origins takes on a particular emphasis due to the growing influence of the genetic paradigm. In the wake of the 
discovery of the structure of DNA, there emerged what Maggie Kirkman (2003) terms an "escalating discourse of the significance of genes and genetic inheritance" (p. 2230). Gradually over the course of the twentieth century, the cell came to be conceptualised as the basic unit or "essence" of life; as "what one is really made of" (Conrad, 1997, p. 142), and rapidly became a cultural icon (Nelkin \& Lindee, 1995; Franklin, Lury \& Stacey, 2000). DNA and genes contained within the cell are now held to reveal the truth of biological origins, and are popularly perceived as causal elements that determine everything from hair and eye colour to personality and behaviour. In keeping with this creeping "genetic essentialism" (Nelkin \& Lindee, 1995), there has been an escalation of claims about genetic bases for various diseases, capacities, behaviours and social problems; including intelligence, sociability, criminality, alcoholism, and even homosexuality (Lippman, 1992; Conrad, 1997). This kind of "genestalk" (Kitcher, 1996, as cited in Conrad, 1997) has intensified in the wake of the Human Genome Project and attempts to map the human genetic structure.

With the rise of this genetic paradigm, social and environmental contributors to social behaviour have become increasingly downplayed and marginalised in favour of explanations that privilege hereditary influences (Conrad, 1997). Indeed, social constructivism is characterised by some local commentators as an "out-of-date" ideology that science has exposed as "deeply flawed": "Nowadays we understand the power of genetic inheritance, with the right to know one's origins considered a fundamental building block of human development" (Sumner-Burstyn, 2002, p. A17). This new genetic essentialism increasingly informs contemporary notions of subjectivity and citizenship, with genetic inheritance often privileged as the most important component of identity, as opposed to just one among many (and often more influential) contributing elements such as social environment, socialisation, interactions with social parents, and life experiences. Further, since each parent supplies one half of the child's all-important gametes, an equalisation has occurred in the perceived relative contribution of fathers versus mothers; one that potentially elevates the status of 
fathers whilst downplaying the mother's more substantial, embodied contribution--a point also noted by Raymond (1993).

The conflation of these discourses is clearly evident in Aotearoa/New Zealand adoption law, and underpinned the shift toward open adoption practices along with subsequent legal changes allowing adult adoptees to trace their birth families (Else, 1991). Traditionally, both closed adoption and anonymous sperm donation were justified on the basis of a belief that secrecy was in the best interests of the child and necessary to preserve the child's relationship with other family members--particularly the social father in cases of DI--and to prevent potential social stigma and isolation (see Cook, Golombok, Bish, \& Murray, 1995; Frith, 2001; Lycett, Daniels, Curson, \& Golombok, 2005). In the case of DI, the parent's right to privacy (guaranteed under UN Conventions) has also been cited as an argument against mandatory openness, with some arguing that parents have the right to keep such information confidential (see Shenfield \& Steele, 1997; Walker \& Broderick, 1999, as cited in Kirkman, 2003). Since the 1970s, however, and consistent with the genetic "turn", a shift in emphasis has occurred from affinal to biological relationships, predicated on strongly held beliefs--and substantial supporting evidence--that family secrets are psychologically harmful and dangerous, that whakapapa needs to be preserved, and that children have the need and right to know about their genetic and social origins (Else, 1991; Daniels, 1998, 2004; Daniels \& Taylor, 1993).

Together, these powerful discourses have informed much of the public, political, and media discussion of proposed legislation governing the provision and use of ART. Various experts have publicly affirmed the importance of knowing one's genetic history for "biological or genetic reasons as well as psycho-social reasons" (Professor Ken Daniels, as cited in Agnew, 2004, p.1), and have posited such knowledge as a fundamental human right. Openness has been said to be essential to creating a "healthy environment" within the family (Alley, 2004, 
p. 3), and much emphasis has been placed on the need for honesty in order to preserve the welfare and well being of the child. Politicians on all sides of the political spectrum echoed these sentiments in Parliamentary debates over the content and scope of the recently introduced Human Assisted Reproductive Technology Act 2004:

It is extremely important that people have access to their genealogical history, that they know where they belong, and that they know various important elements of their identity. (Jill White, Labour MP, Hansard, 23.4.97)

The child has the right to know. (Lianne Dalziel, Labour MP, Hansard, 17.11.98)

All children deserve to know their whakapapa... They should know their ethnicity and where they come from." (Judith Collins, National MP, Hansard, 6.10.04)

Lack of knowledge of genetic heritage, on the other hand, was said to disrupt one's sense of personal identity, potentially leading to a debilitating sense of loss and feelings of “genealogical bewilderment" (Else, 1999, p. 58), a term originally coined by Sants (1964, as cited in Frith, 2001) in relation to adopted children. The once standard practices of closed adoption and anonymous sperm donation were similarly said to have resulted in dangerous family secrets and associated fear, anxiety, and distress when later revealed (Else, 1991; Oliver, 2002; Daniels, 1998; Daniels \& Taylor, 1993).

While it is vitally important to acknowledge the very real distress felt by many adopted and DI children when unable to access knowledge about their genetic parent(s), it is also important to consider whether at least some of this distress may actually be intensified by this hybrid discourse and its tendency to overvalue genetic contributions in ways that effectively devalue significant sources of personal identity not "based" in biology. Indeed, some local commentators have taken genetic essentialism to its natural conclusion by implying individuals are quite literally the sum of their genes: "half a genetic heritage does not a whole person make" (Sumner-Burstyn, 2002, p. A17). This genetic reductionism is also evident in 
descriptions of those who lack "vital" knowledge about their sperm donor father as “anonymous children” (Ibid; Walsh, 2004b, p.14). Such descriptions imply that identity is entirely conveyed through the father's genetic contribution, and resonate with once widely held notions of the homunculus, whereby the father's "active" seed was held to deposit a miniature human being within a passive female body that served merely as its incubator. By characterising donor offspring as somehow "anonymous", the genetic, biological, and social reality of the child's connection to his or her mother is effectively erased in a way that boosts the prominence of what Janice Raymond (1993, p. 30) terms "ejaculatory fatherhood". Also erased are wider kinship relationships within the child's social environment, including to the social father or lesbian co-parent if there is one, and genetically-unrelated extended family members. Only by denying such maternal and relational connectedness can a donor child be considered in any way "anonymous".

Further, it is important to recognise that moves to ensure open access to genetic information have been at least partly fuelled by underlying social and political anxieties about the identity and status of fathers. Citing figures on the high proportion of single women and lesbian couples using "IVF" [sic] $]^{\mathrm{viii}}$, one MP suggests "This fact alone makes it extremely clear why the issue of children being able to access in later years that important information about the identity of their father will become even more substantial" (Judy Turner, United Future MP, Hansard, 6.10.04; emphasis added). No clue is offered as to why a donor child's need to know their genetic heritage should be any more pressing simply because they were not born into a conventional heterosexual nuclear family, suggesting that knowing one's genetic father is considered especially necessary for those who lack a social father, presumably to compensate for the "deficit" of being born into an "unnatural" family situation. It would thus appear that in the current context, one of the 'necessary' functions of social regulation is to appease cultural anxieties generated by the challenge certain uses of ART pose to the traditional family structure and the status of fathers within it. In the Aotearoa/New Zealand 
context, these anxieties appear to have been partially resolved by symbolically restoring the pre-eminence of the father, if only in a social and legal sense.

\section{“Knowing" The Father}

Indeed, concerns about the role and status of men and fathers have been raised in relation to a number of issues in Aotearoa/New Zealand since the 1970s, including the introduction of the Domestic Purposes Benefit for single mothers, perceived biases in the Family Court's resolution of child custody disputes, the apparent under-achievement of boys in schools, and the (internationally reported) "dominance" of positions of political and civic leadership by women, including Prime Minister Helen Clark, Governor-General Dame Sylvia Cartwright, former Attorney-General Margaret Wilson, and Chief Justice Dame Sian Elias (Ashley, 2001; Wishart, 2003). More recently, media have reported new developments in the areas of haploidisation and parthenogenesis, raising the prospect that even sperm donors might now be inessential, and that women might soon be able to reproduce without men. As one journalist asks, "Who is the "father" if two women have a baby? Is there a "father"?" (Walles, 2003, p.7). In a biological sense the answer is quite straightforward and selfevident: there simply is no father. Clearly, however, such a situation remains culturally inconceivable, and must be guarded against.

Hence, in the wake of rising rates of single and lesbian motherhood via anonymous sperm donation, increasing unease has been expressed not just concerning children lacking "essential" knowledge about their biogenetic heritage, but also about children "growing up without dad". In the case of anonymous donation, this generalised unease neatly articulates with the discourses of children's rights and genetic essentialism, as with taken-for-granted assumptions regarding the desirability of a paternal influence. It is this conflation of elements that prompts even influential feminist commentators such as Sandra Coney to argue that the state has a specific obligation not to facilitate social and legal fatherlessness: 
Is it acceptable for the state to cooperate in the creation of children where no father will be entered on the birth certificate, and there is no intention for the father to be involved in the upbringing of the child or in the child's life? ... These arrangements deny the child a legal father and the possibility of a claim on his estate after he dies.... At the very least, this situation calls for some examination of arrangements for the involvement of alternative "father figures" in the child's life and for mandatory openness about the identity of the donor father. (Coney, 1999, p.44-45)

Implicitly acknowledged here is the fact that there is no longer any necessary relationship between biological, legal, and social fatherhood: A great deal of substitution within and between roles is now possible. It is this new fluidity--generated and exacerbated by ART's separation and dispersal of fatherhood into its component parts--that appears to provoke the contemporary unease. That is to say, the separation of men's (already inherently disembodied) genetic contribution to human reproduction from heterosexual sex itself--and more importantly from those patriarchal socio-legal institutions that historically embodied as well as enacted patriarchal power--poses a particularly potent threat to men's privileged status. While it is undeniably true that reproduction has also been separated from its traditional "unity with the female body" through IVF and the emergence of visual technologies that render the womb transparent (Lie, 2002, p.394), women as a group (for now at least) retain a necessary and visibly embodied relationship to reproduction through the physical acts of gestation and childbirth. The egg fertilised through IVF must, after all, return to a female body. Conversely, all that is required of men is their genetic contribution, and even that is now increasingly under threat. Lacking an irrefutable "natural" connection to guarantee their parental standing and rights, the status of fathers has always had to be established in name and in law (most notably, within the institutions of marriage and the family) in order to assert a cultural and social linkage in place of a tenuous and contestable "natural" one (Ibid.). Hence, it is no coincidence that just as those institutions and traditional social linkages are fading in significance, we see a renewed cultural emphasis on the 
centrality of fathers to the identities of their children; a notion wholly supported and indeed reinforced by the present cross-articulation between the discourses of children's rights and genetic essentialism, and in consequent policy and practice.

Thus, recent years have seen a proliferation of public debate, policy, and social activism seeking to clarify and reaffirm the status and role of fathers and to reintegrate the fractured biological, legal, and social components of fatherhood. This is evidenced in the rise of the men's rights movement--expressed locally in groups such as the Union of Fathers--and in the conservative gender politics of the Destiny Church and related political party, Destiny New Zealand, ${ }^{\text {ix }}$ all reasserting patriarchal authority in both public and private domains. It is also evident in high-powered calls for legislation to recognise the legal rights of known sperm donors where the donor anticipated having an ongoing relationship with the child--but only in cases of DI involving lesbians and single women (Devereux, 2003). Related measures designed to clarify the legal status and responsibilities of those caring for children have similarly (and ironically) affirmed the centrality of fathers, even while formally recognising alternative family forms. A draft version of the Care of Children Bill provoked considerable public outcry when it proposed including the lesbian partner of a child's mother under the label of "legal father of the child" to save words in the draft bill (Tunnah, 2003). While formal recognition of same-sex parents is highly progressive and somewhat overdue, such wording again reflects the symbolic importance attached to the father, who must always be rendered visible and present. Even when no biological father is actually in the picture, someone must stand in his place. Predictably, many took issue with the notion that this "someone" might be a woman: "Our objection is to the bill saying a lesbian partner is a father.... this is about fathers being men" (National MP Nick Smith, as cited in Tunnah, 2003, p.A7; emphasis added). 


\section{Legislating Openness: The Human Assisted Reproductive Technology Bill 2004}

It is within this wider context that the Human Assisted Reproductive Technology (HART) Bill was written, debated and finally passed into law in 2004. This legislation enshrines "the health and well-being of children" conceived via ART as an "important consideration in all decisions" about such procedures (4(a)), and legally recognises donors while also ensuring their medical histories and other information is stored in a centralised register and available to donor offspring once they turn 18. The bill includes the clauses 4(f), "donor offspring should be made aware of their genetic origins and be able to access information about those origins", and 45(3)(g), which states that service providers must ensure prospective guardians are told of "the importance of telling offspring about the nature of their conception". This wording actually represents something of a watering down of an original recommendation by the Health Select Committee, which would have required those undergoing fertility treatment to agree, as part of the consent process, to tell their child if a gamete or embryo donor was used in their conception (Health Select Committee, 2004).

Significantly, this mandatory requirement to use identifiable donors merely formalises what has actually been common practice in most local clinics for the past 10 years. Given the discursive shifts discussed above, non-anonymous donation has come to be widely regarded in Aotearoa/New Zealand as the only morally and ethically responsible option, and is seen as necessary to protect the child's fundamental right to know his or her genetic heritage and to ensure their psychological welfare and well-being. These views are strongly asserted, despite considerable disagreement internationally about the relative merits of identifiable versus anonymous donation. ${ }^{\mathrm{x}}$ Under the HART legislation, individuals and couples will have one choice imposed by the state and reinforced by clinics themselves--that of an identifiable donor--effectively denying would-be parents "the freedom to decide for themselves which donor type would fit in their particular family concept" (Brewaeys, 1998, p.2348), and also denying them the opportunity to make an autonomous ethical judgement. 
Yet even those who strongly advocate openness acknowledge there is little empirical evidence that children conceived via anonymous sperm donation suffer serious psychological harm compared to those who will have the opportunity to know their donor ${ }^{\mathrm{xi}}$ (Daniels, 2004; Lycett et al., 2005). Much of the current thinking draws on suppositions derived from adoption research, which some argue is an inaccurate and unwarranted comparison since donor children are usually biologically related to one parent and have not been "abandoned" or "given away" (Shenfield \& Steele, 1997; Golombok, 1998). Nor is there sufficient research into the potential psychological effects of disclosure and identification of the donor on the child, on existing family relationships (particularly with the non-biological parent) (Scheib, Riordan, \& Rubin, 2003; Lycett et al., 2005), or on the consequences for those who seek out a donor parent and encounter an individual who differs from prior expectations and/or reacts in ways that were not fully anticipated. Despite the lack of decisive evidence either way about the potential for harm to the child's health and overall well being, the HART Bill not only requires identifiable donors, but more problematically, formalises a growing degree of official surveillance and regulation of those seeking to create a family through gamete and embryo donation, a significant number of whom comprise single women and lesbian couples using DI. This aspect clearly warrants further consideration.

\section{External and Internal Surveillance Techniques}

As reproduction becomes more of a public act, "a commercial transaction, and a professionally managed procedure" (Franklin, 1997, p.14), it is exposed to greater levels of surveillance and control by the (nation) state (McElroy, 2002). Such control is evident in the regulatory framework and policies set in place by the HART Bill, which concretise the operation of ART as a set of disciplinary practices or techniques in a Foucauldian sense. As Sawicki (1991) and Shildrick (1997) suggest, ARTs can be seen as technologies that monitor, control, and regulate (particularly) women's bodies, behaviours and capacities in defined 
ways that "aim to render the individual both more powerful, productive, useful and docile" (Sawicki, 1991, p. 68). In the process, these technologies create new maternal subject positions--they make it possible to be an "infertile mother", a 'surrogate mother", a "postmenopausal mother", a "lesbian mother", a "worthy" or "unfit" mother--but in so doing, they also bring the "institution and meaning of motherhood...even deeper into the realm of controlling normativities" (Shildrick, 1997, p.187). For example, Aotearoa/New Zealand's CPAC criteria include normative provisions that allow clinicians to refuse treatment to women who are considered too old, are unwilling to give up smoking, or unable to lose weight; and as previously noted, many countries exclude single women and lesbian couples from receiving treatment on the grounds that they would constitute unfit, selfish, and deviant mothers. Thus, while ARTs themselves expand the range of potential maternal subject positions, their regulation serves to contract it by "attaching individuals to specific identities, and establishing norms against which individuals and their behaviours and bodies are judged and against which they police themselves." (Ibid.).

The regulatory context governing the provision and use of ART in Aotearoa/New Zealand plays a key role in determining which individuals can be attached to specific maternal identities, and in so doing simultaneously constructs and reinforces the boundaries between "acceptable" and "undesirable" motherhood. But the real disciplinary work occurs where these regulatory imperatives and criteria are activated at the level of the clinic in the form of more rigorous and detailed record-keeping (with identifying information forwarded to a national register), more intensive monitoring of clients both during and after treatment (since clinics must now record if and when donor offspring are born) and in the micro-processes that explicitly and implicitly screen clients for their suitability for treatment whilst also imparting to them "required" knowledges. That is to say, in the various meetings between clients and fertility specialists, nurses, counsellors, and technicians. For example, where clients are using gamete donation, all Aotearoa/New Zealand clinics strongly recommend or 
even require clients to have at least one interview with an "independent" counsellor--itself an oxymoron, since counsellors are commonly on-site and employed by the clinic. This is seen as necessary to ensure clients have "thought through" the relevant issues and are informed of the importance of telling children about their origins, along with age appropriate ways of doing this ('Rachel' and 'Jennifer', xii personal communications, August 27, 2003 and October 16, 2003). With the new statutory requirements of clinics to inform clients of the importance of openness about genetic origins, more extensive counselling is likely to become compulsory.

Counselling sessions, which are primarily intended to offer much needed emotional support and information to clients at various treatment stages, serve a dual purpose in terms of confirming clients' suitability for treatment through the absence of any factors that may detrimentally affect the welfare of the child. As such, mandatory counselling can be understood in terms of Foucault's notion of the confessional, in which the presentation of self unfolds "within a power relationship" in which "the authority who requires the confession, prescribes and appreciates it and intervenes in order to judge, punish, forgive, console, and reconcile" (Foucault, 1998, p.61-62), or in this case, to ensure clients are suitably informed and will constitute "suitable" parents. In the case of infertility counselling, clients' selfpresentation allows the clinic to assess their suitability as potential parents and to identify any issues that might compromise the child's future interests. If serious issues are "confessed"-such as past physical or sexual abuse, or drug dependence--these are likely to be discussed with the wider treatment team, and may lead to treatment being postponed or declined ('Rachel', personal communication, August 27, 2003). While in some cases this may be entirely appropriate, the absence of explicit guidelines specifying which circumstances warrant intervention means much is left to the subjective judgement and discretion of counsellors and clinicians themselves. 
Given current socio-political and regulatory imperatives, we may see a widening of the circumstances regarded as compromising the child's best interests. For example, the degree to which clients have internalised hegemonic discourses regarding the significance of genetic origins may come to form part of the implicit criteria shaping clinical determinations of clients' suitability and "worthiness" to parent. While many clients believe their child should know how they were created and be aware of their genetic heritage, even those who do not are likely to be aware of the necessity of professing their intention to tell their child about the circumstances surrounding their birth. Given newly imposed statutory requirements, such an intention could gradually solidify into a more explicit requirement. Problematically, however, such an intention does not guarantee parents will follow through (see Brewaeys, Ponjaert, Van Hall, \& Golombok, 1997; Gottlieb, Lalos, \& Lindblad, 2000).

Obviously, in the case of single women and lesbian couples, some explanation must presumably be offered for the absence of a father. Hence, these groups have exceedingly high rates of disclosure or plans for it (Brewaeys, 2003; Leiblum, Palmer, \& Spector, 1995). Notably, Brewaeys, de Bruyn, Louwe, and Helmerhorst (2005) found that all but one of the 41 lesbian couples surveyed in a recent Dutch study consciously chose identifiable rather than anonymous donors--a significantly higher proportion than among heterosexual couples-suggesting very little basis for claims of lesbian "maternal egoism". Additional implicit requirements, however, may operate in terms of the need for these women to monitor their behaviour and self-presentation to offer reassurance of their "normality" and suitability for motherhood. Given that it is commonly believed to be in the best interests of the child to have a central male role model in their life, determinations of the suitability of single women and lesbian couples are already partly informed by evidence that these women are willing to ensure an appropriate father "substitute" is actively available to stand in the place of the absent biological and social father ('Rachel', personal communication, August 27, 2003). In the case of lesbian couples, a further approximation of "normality" might be achieved by 
conforming as closely as possible to dominant ideals of the family as a middle-class, selfcontained economic unit, perhaps even mimicking the traditional division of domestic labour in which one partner works while the child bearer is a stay-at-home mother. In this way, lesbian families may become "families in drag" (Malone and Cleary, 2002, p.274), actively mitigating their sexual deviancy through a performance of familial normality. As Cooper and Herman (1991) note, "the acceptability of lesbians and gay men is predicated upon their reproduction of dominant behaviours, values, and culture" (p. 78), which in turn serves to both reinforce familial ideology and further marginalise those unable or unwilling to conform so successfully due to their socio-economic class, ethnicity, lifestyle choices, or political beliefs.

Failure to sufficiently comply with these implicit criteria may be interpreted as indicative of a lack of suitability for treatment, and while clinics are effectively hamstrung in declining treatment on grounds that contravene human rights legislation, they do have the discretion to deny treatment if they feel the best interests of the child will not be served. They may also actively dissuade certain clients, respond more negatively to them, or require them to further consider the "relevant issues" before proceeding with treatment, just as they may require women to lose weight or stop smoking. However, such external monitoring and surveillance is often not necessary, given that clients themselves engage in forms of self-surveillance and regulation that lead them to successfully conform to both explicit and implicit treatment criteria.

\section{Unintended Consequences?}

It also appears that the current regulatory regime may have a number of undesirable consequences. Identifiable sperm donation has been accompanied in Aotearoa/New Zealand by a pronounced decrease in the number of willing sperm donors, which has dropped to less than a fifth of the numbers available in the late 1980s (Walsh, 2004a). A similar decline has 
been noted in other national contexts where identifiable donation has been legislated, including Italy, Sweden, the Netherlands, Norway, Australia, and most recently the United Kingdom. In Victoria, Australia, clinicians report that "recording identifying information had reduced the number of both male and female donors prepared to donate by 90 percent amongst men and a slightly lower proportion of women" (Western Australia, 1999, as cited in Frith, 2001, p. 820). Studies into donor attitudes towards non-anonymity also reinforce the potential for further decline in numbers (see Frith, 2001).

Local donors (who under current anti-commercialisation provisions cannot be paid for their services) also quite reasonably wish to have a say in who can receive their gametes. Unfortunately, a significant number currently choose to exclude lesbian couples, and some also exclude single women, prompting concerns about the long-term consequences of using a limited sperm pool for a relatively small group of families, including fears of incestuous relationships later forming between donor offspring (McLean, 2002). Such concerns have already led to lengthy waiting periods, restrictions on the use of a small and declining sperm pool, and increased surveillance of lesbians and single women seeking sperm donation (Ibid; Managh, 2004b). Since few donors supply sperm for the exclusive use of lesbians and single women, clinics may eventually be unable to offer DI to single and lesbian women, as one specialist has already forewarned (Dr Margaret Merilees, as cited in McLean, 2002, p.4).

Among heterosexual couples, declining availability of donor sperm is intensifying the trend toward using ICSI to overcome male factor infertility, a procedure which has significantly greater negative consequences for the female partner since it requires her to undergo the physical and emotional stresses, risks, and significantly greater financial costs involved with (potentially multiple) IVF cycles. While these couples escape becoming the objects of an increasingly intrusive degree of official scrutiny and regulation, both male and especially female partners become subjected instead to rather more consequential medical surveillance 
and invasive physical intervention, with all that this entails. Meanwhile, fertility clinics reap the financial rewards that flow from the transformation of a large part of their client base from being recipients of a low cost, low-tech procedure (DI) into candidates for one of their more expensive and invasive procedures (IVF with ICSI), whilst simultaneously gaining kudos for having so willingly embraced the shift toward identifiable donation.

Additional negative consequences flow from the inability of licensed clinics to service growing demand from single women and lesbian couples. It seems likely that these women will increasingly rely on informal networks and potentially dangerous practices to aid conception, such as having unprotected heterosexual sex, self-inseminating unscreened sperm supplied by a male acquaintance, purchasing sperm through unauthorised and unregulated "grey market" services ${ }^{\text {xiii }}$--or seeking treatment overseas as part of an emerging fertility tourism. Most of these measures entail greater risks and potential harms in terms of possible transmission of genetic disorders and infectious diseases such as herpes, hepatitis $\mathrm{C}$ and $\mathrm{HIV}^{\mathrm{xiv}}$, and less security about the legal rights and responsibilities of all parties involved (see also Walker, 2003). Lack of medical supervision also makes it more difficult to establish the donor's fertility, along with the biologically optimal time to attempt conception, leading to higher failure rates. All these situations are entirely unregulated in terms of the official recording of donor information, ironically exacerbating the very situation legislators and other commentators apparently fear: The proliferation of children who lack access to information about a donor parent's medical history and genetic heritage. On the positive side, self insemination resists what some regard as the unnecessary level of medicalisation of DI and frees women from growing levels of intrusive state regulation and professional surveillance of their reproductive capacity, and can thus be viewed as a potential nexus of feminist resistance to increasingly oppressive state controls (as noted by Klein, 1984). 


\section{Conclusion}

As this paper has illustrated, just as larger numbers of certain groups of women are seeking to use DI and IVF to reproduce outside of hetero-patriarchy, there has emerged an escalating imperative asserting the importance of "knowing" one's genetic origins and of "knowing" the father. This imperative is increasingly operationalised in ways that control and regulate the reproductive choices and capacities of single and lesbian women in particular. It is expressed through the use of particular representational strategies and disciplinary techniques that effectively contain the extent to which hetero-normative assumptions can be transgressed through particular uses of ART, whilst simultaneously affirming hegemonic meanings and performances of "gender", "motherhood", and "family". In this manner, any challenge that transgressive uses of ART might pose to patriarchal reproductive hegemony has been partially neutralised within the local cultural imaginary, and potentially also in actual practice, given increasingly vocal conservative opposition to progressive social reforms. ${ }^{\mathrm{xv}}$ It is also clear that in the current social, political, and discursive context, many believe that this is rightly so; that the rights and interests of children conceived through gamete donation should be preserved and upheld, irrespective of whether resulting policy and practice constrains the reproductive choices and capacities of certain marginalised groups.

In drawing attention to some of those existing and potential constraints, it is not my intention to dispute the need for some form of regulation of the provision and use of ART, since there clearly are legitimate grounds to deny certain individuals access to treatment in certain circumstances (see Walker, 2003, for a detailed discussion). Rather, my primary objective is to contribute to an ongoing dialogue about the implicit assumptions underpinning policy and practice in this area, and to question whether highly prescriptive forms of regulation are entirely warranted and justified, based not on received belief and "common-sense" understandings, but rather on solid research evidence. As this paper illustrates, while great strides have been made in Aotearoa/New Zealand to eliminate explicitly discriminatory laws 
and practices, implicit discriminations may persist when those laws and practices are grounded in unchallenged hetero-normative discursive presumptions. Thus, seemingly inclusive policies may in fact result in further exclusion, marginalisation, surveillance and regulation of groups who fail to conform to dominant social norms, and may have unintended consequences that unfairly limit the reproductive choices of certain individuals whilst exposing others to unnecessary medical and psychological risks. 


\section{References:}

Agnew, Margaret. (2004, November 16). Telling the truth. The Press, p.1.

Alley, Oskar. (2004, August 7). Fertile ground. The Dominion Post, p. 3.

Ashley, Jackie. (2001, April 2). New Zealand, a woman's land. The New Statesman. Retrieved November 29, 2005, from http://www.newstatesman.com/nssubsfilter.php3? newTemplate=NSArticle_NS\&newDisplayURN=200104020011

Balsamo, Anne. (1996). Technologies of the gendered body: Reading cyborg women. Durham \& London: Duke University Press.

Batty, Lynne. (2002). Assisted reproductive technology: The Aotearoa/New Zealand policy context. Unpublished Masters thesis. University of Canterbury, Christchurch, New Zealand. Bennett, Belinda. (2000). Reproductive technology, public policy and single motherhood. Sydney Law Review, 22, 625-635.

Brewaeys, Anne. (2003). Lesbian couples in DI practice. In Jennifer Gunning \& Helen Szoke (Eds.), The regulation of assisted reproductive technology (pp. 141-150). Hampshire, England: Ashgate Press.

Brewaeys, Anne. de Bruyn, J.K., Louwe, L.A. and Helmerhorst, F.M. (2005). Anonymous or identity-registered sperm donors? A study of Dutch recipients' choices. Human Reproduction, 20, 820-824.

Brewaeys, Anne, Ponjaert, Ingrid, Van Hall, E.V., \& Golombok, Susan. (1997). Donor insemination: child development and family functioning in lesbian mother families. Human Reproduction, 12, 1349-1359.

Bryld, Mette. (2001). The infertility clinic and the birth of the lesbian: The political debate on assisted reproduction in Denmark. European Journal of Women's Studies, 8, 299-312. 
Cannold, Leslie and Gillam, Lynn. (2003). A new consultation management process for managing divergent community views: Lesbian and single women's access to artificial insemination and ARTs. In Jennifer Gunning and Helen Szoke (Eds.). The regulation of assisted reproductive technology (pp. 203-224). Ashgate Press: Hampshire.

Chisholm, Donna. (2002, June 9). When Bob and Mary tried for a baby. Sunday Star Times, pA2.

Coney, Sandra. (1999). The rights and interests of the child. In Sandra Coney \& Anne Else (Eds.), Protecting our future: The case for greater regulation of assisted reproductive technology: A discussion document (pp. 41-49). Auckland, New Zealand: Women's Health Action Trust.

Conrad, Peter. (1997). Public eyes and private genes: Historical frames, news constructions, and social problems. Social Problems, 44, 139-154.

Cook, R., Golombok, Susan, Bish, A. and Murray Clare. (1995). Disclosure of donor insemination: parental attitudes. American Journal of Orthopsychiatry, 65, 549-559.

Cooper, Davina \& Herman, Didi. (1991). Getting "the family right": Legislating heterosexuality in Britain, 1986-1991. Canadian Journal of Family Law, 10, 41-78.

Corea, Gena. (1985). The mother machine: Reproductive technologies from artificial insemination to artificial wombs. New York: Harper and Row.

Daniels, Ken R. (1995). Information sharing in donor insemination: a conflict of rights and ends. Cambridge Quarterly of Healthcare Ethics, 2, 217-224.

Daniels, Ken R. (1998). Assisted human reproduction in New Zealand: The contribution of ethics. Eubios: Journal of Asian and International Bioethics, 8, 79-81. 
Daniels, Ken R. (2004). New Zealand: From secrecy and shame to openness and acceptance. In Eric Blyth \& Ruth Landau. (Eds.), Third party assisted conception across cultures: Social, legal and ethical perspectives. London: Jessica Kingsley.

Daniels, Ken R. \& Burn, I. (1997). Access to assisted human reproduction services by minority groups. Australia and New Zealand Journal of Obstetrics and Gynaecology, 31, 7985.

Daniels, K. R. \& Taylor, K. (1993). Secrecy and openness in donor insemination. Politics and the Life Sciences, 2, 155-170.

Devereux, Monique. (2003, January 31). Old law leaves sperm donor dad out in cold. New Zealand Herald, p. A1.

Else, Anne. (1991). A question of adoption. Wellington, New Zealand: Bridget Williams Books.

Else, Anne. (1999). Longer term issues: Information, access, truth, openness and contact. In Sandra Coney \& Anne Else (Eds.). Protecting our future: The case for greater regulation of assisted reproductive technology: A discussion document (pp. 57-61). Auckland, New Zealand: Women's Health Action Trust.

Farquhar, Dion. (1996). The other machine: Discourse and reproductive technologies. New York \& London: Routledge.

Foucault, Michel. (1998). The will to knowledge: The history of sexuality (Vol. 1). (R. Hurley, Trans.). London: Penguin.

Franklin, Sarah. (1990). Deconstructing "desperateness": The social construction of infertility in popular representations of new reproductive technologies. In Maureen McNeil, Ian Varcoe, \& Steven Yearley. (Eds.), The new reproductive technologies (pp. 200-229). London: MacMillan. 
Franklin, Sarah. (1997). Embodied progress: A cultural account of assisted conception. London: Routledge.

Franklin, Sarah, Lury, Celia, and Stacey, Jackie. (2000). Global nature, global culture. London: Sage.

Frith, Lucy. (2001). Gamete donation and anonymity: The ethical and legal debate. Human Reproduction, 16, 818-824.

Golombok, Susan. (1998). New families, old values: Considering the welfare of the child. Human Reproduction, 9, 2342-2347.

Golombok, Susan. (2000). Parenting: What really counts? London: Routledge.

Gottlieb, Claes, Lalos, Othon, \& Lindblad, Frank. (2000). Disclosure of donor insemination to the child: The impact of Swedish legislation on couples' attitudes. Human Reproduction, 15, 2052-2056.

Hartouni, Valerie. (1997). Cultural conceptions: On reproductive technologies and the remaking of life. Minneapolis: University of Minnesota Press.

Health Funding Authority. (2000). Gynaecology referral guidelines and prioritisation criteria. Wellington, New Zealand: Health Funding Authority.

Health Select Committee. (2004, August). Report on the Human Assisted Reproductive Technology Bill. Wellington, New Zealand: Government Printing Office. Retrieved August 9, 2004, from http://www.parliament.govt.nz/

Karpf, Ann. (1988). Doctoring the media: The reporting of health and medicine. London: Routledge.

Kirejczyk, Marta. (1994). Feminist discourse, gender and social entrenchment of in vitro fertilization in the Netherlands. The European Journal of Women's Studies, 1, 151-164. 
Kirkman, Maggie. (2003). Parents' contributions to the narrative identity of offspring of donor-assisted conception. Social Science \& Medicine, 57, 2229-2242.

Klein, Renate Duelli. (1984). Doing it ourselves: Self insemination. In Rita Ardittain, Renate Duelli Klein, \& Shelley Minden (Eds.), Test-tube women (pp. 382-290). London: Pandora Press.

Klein, Renate. (1991). Women as body parts in the era of reproductive and genetic engineering. Health Care Women International, 12, 393-405.

Leiblum, Sandra R., Palmer, M. G., \& Spector, I. P. (1995). Non-traditional mothers: Single heterosexual/lesbian women and lesbian couples electing motherhood via donor insemination. Journal of Psychosomatic Obstetrics \& Gynaecology, 16, 11-20.

Lie, Merete. (2002). Science as Father? Sex and gender in the age of reproductive technologies. European Journal of Women's Studies, 9, 381-399.

Lippman, Abby. (1992). Led (astray) by genetic maps: The cartography of the human genome and health care. Social Science \& Medicine, 35, 1469-1476.

Lycett, Emma, Daniels, Ken, Curson, Ruth, \& Golombok, Susan. (2004). Offspring created as a result of donor insemination: A study of family relationships, child adjustment, and disclosure. Fertility and Sterility, 82, 172-179.

Lycett, Emma, Daniels, Ken, Curson, Ruth, \& Golombok, Susan. (2005). School-aged children of donor insemination: A study of parents' disclosure patterns, Human Reproduction, 20, 810-819.

Malone, Kareen \& Cleary, Rose. (2002). (De)Sexing the family. Feminist Theory, 3, 271293. 
Managh, Cushla. (2004a, August 16). "He was worth every dollar I spent". The Dominion Post, p.A5.

Managh, Cushla. (2004b, August 16). Lesbians and singles lead donor births. The Dominion Post, p. A5.

McElroy, Ruth. (2002). Whose body, whose nation? Surrogate motherhood and its representation. European Journal of Cultural Studies, 5, 325-342.

McLean, Roslind. (2002, May 12). Sperm donor shortage alarms. Sunday Star Times, p.4.

New Zealand Listener. (1995, January 21). Who is left holding the baby? New Zealand Listener, 147 (2857), pp.14-15.

New Zealand Ministerial Committee on Assisted Reproductive Technologies (1994). Assisted human reproduction: navigating our future: Report of the Ministerial Committee on Assisted Reproductive Technologies. Wellington, New Zealand: Tribunals Division, Department of Justice.

Murray, Clare. (2004). Same-sex families: Outcomes for children and parents. Family Law, 4, 136-139.

Nelkin, Dorothy, \& Lindee, M. Susan. (1995). The DNA mystique: The gene as a cultural icon. New York: W.H. Freeman.

Nisbet, Matthew, Brossard, Dominique, \& Kroepsch, Adrianne. (2003). Framing science: The stem cell controversy in an age of press/politics. Press/Politics, 8(2), 36-70.

Nixson, Matt and Knowsley, Jo. (2004, June 20). Morals not included. The Mail on Sunday, p.16.

Oliver, Annie. (2002, November 5). Donating a family. The Press, p.5. 
Pattinson, Shaun D. (2003). Current legislation in Europe. In Jennifer Gunning \& Helen Szoke (Eds.), The regulation of assisted reproductive technology (pp. 7-20). Hampshire, England: Ashgate Press.

Paxson, Heather. (2003). With or against nature? IVF, gender and reproductive agency in Athens, Greece. Social Science \& Medicine, 56, 1853-1866.

Petersen, Alan. (2001). Biofantasies: genetics and medicine in the print news media. Social Science \& Medicine, 52, 1255-1268.

Raymond, Janice. (1993). Women as wombs: Reproductive technologies and the battle over women's freedom. San Francisco: HarperSanFrancisco.

Sawicki, Jana. (1991). Disciplining Foucault: Feminism, power and the body. London \& New York: Routledge.

Scheib, Joanna E., Riordan, Maura \& Rubin, Susan. (2003). Choosing identity-release sperm donors: the parents' perspective 13-18 years later. Human Reproduction, 18, 1115-1127.

Shenfield, F. \& Steele, S. (1997). What are the effects of anonymity and secrecy on the welfare of the child in gamete donation? Human Reproduction, 12, 392-395.

Shildrick, Margrit. (1997). Leaky bodies and boundaries: Feminism, postmodernism and (bio)ethics. New York: Routledge.

Sumner-Burstyn, Barbara. (2002, July 29). Secrecy over sperm donors exercise in maternal egoism. New Zealand Herald, p. A17.

Szoke, Helen. (2003). Australia--A federated structure of statutory regulation of ART. In Jennifer Gunning \& Helen Szoke (Eds.), The regulation of assisted reproductive technology (pp. 75-94). Hampshire, England: Ashgate Press. 
Tasker, Fiona \& Golombok, Susan. (1997). Growing up in a lesbian family. New York: Guilford Press.

The Dominion Post. (2004, August 23). Breeding new law [Editorial]. The Dominion Post, p.4.

Tunnah, Helen. (2003, June 12). Ms Dad exposes bill's gender bending clause. New Zealand Herald, p.A7.

Turner, Amanda and Coyle, Adrian. (2000). What does it mean to be a donor offspring? The identity experiences of adults conceived by donor insemination and the implications for counselling and therapy. Human Reproduction, 15, 2041-2051.

Walker, Kristen. (2003). Should there be limits on who may access assisted reproductive services? A legal perspective. In Jennifer Gunning \& Helen Szoke (Eds.), The regulation of assisted reproductive technology (pp. 123-140). Hampshire, England: Ashgate Press.

Walles, Hayden. (2003, August 23). New ways to make babies. The Press, p.7.

Walsh, Rebecca. (2004a, August 24). Sperm donor shortage. New Zealand Herald, p.A3.

Walsh, Rebecca. (2004b, October 9-10). Still searching for the man who made her. Canvas, p.14.

Wishart, Ian. (2003, November). The siege of Helengrad. Investigate Magazine. Retrieved on November 29, 2005, from http://www.investigatemagazine.com/nov03paradise.htm

Yates, Dianne. (2001, May 26). Swimming in the gene pool (legislative progress). Speech presented at the 'Hello Dolly' Seminar, University of Waikato, Hamilton, New Zealand. 


\begin{abstract}
${ }^{\text {i }}$ A popular misnomer; Louise Brown was actually conceived in a petri dish.
${ }^{i i}$ Recent developments in the area of haploidisation suggest that it may become possible for lesbian couples to bear children who are genetically related to both partners through the creation of artificial sperm. A British lesbian couple have already volunteered to be the first to utilise the service, should it become commercially available (Walles, 2003).

iii The media analysis was based on a survey of New Zealand print media representations of reproductive and related biogenetic technologies conducted from $1^{\text {st }}$ May 2002 to $1^{\text {st }}$ September 2003, and from $1^{\text {st }}$ August to $1^{\text {st }}$ December 2004. This survey was limited to the largest circulation newspapers and magazines, including the daily national paper, the New Zealand Herald, and Weekend Herald, the national weekly Sunday Star Times, and three regional daily papers: The Christchurch Press, the Wellington-based Dominion Post, and the Hamilton-based Waikato Times. Also included were the following magazines: Canvas, New Zealand Listener, New Zealand Woman's Weekly, Next, and New Idea.
\end{abstract}

${ }^{\text {iv }}$ The increased use of this technique in Aotearoa/New Zealand must also be understood in the context of the self-imposed policy of some clinics to only offer identifiable donors.

${ }^{\vee}$ See Brewaeys (2003), Brewaeys, Ponjaert, Van Hall and Golombok (1997), Golombok (1998, 2000), Lycett, Daniels, Curson, and Golombok (2004), Murray (2004), and Tasker and Golombok (1997).

${ }^{v i}$ Anecdotally, it appears some fertility clinics have resolved the opposition of certain employees to treating single women and lesbian couples by limiting the nature of that service to that of supplying screened sperm for the purposes of self insemination.

${ }^{v i i}$ Frequently estimated to account for $35-50 \%$ of infertility experienced by heterosexual couples.

viii I assume here that the Honourable Member is referring to donor insemination, as the proportion of those undergoing IVF who are single or lesbian women remains very small, while they now comprise a significant majority of those using DI at some clinics.

${ }^{i x}$ See www.destinychurch.org.nz and www.destinyNZ.org.nz.

${ }^{\mathrm{x}}$ To the best of my knowledge, a number of countries (including France, Denmark and Norway) continue to view the use of anonymous donors as in the best interests of all concerned (Brewaeys, 1998), while in the USA and Ireland, a "double track" system allows parents to choose either identifiable or anonymous donors (Frith, 2001; Scheib, Riordan \& Rubin et al., 2003).

${ }^{x i}$ One frequently cited study is that of Turner and Coyle (2000), which discusses negative reactions among 16 young adults who found out they were conceived by DI later in life (and often under negative circumstances such as parental death or divorce), including feelings of mistrust toward family members, feeling separate and distinct from the rest of the family, feeling abandoned by the donor and fertility specialists, and frustration and loss at not being able to access donor information. However, this small sample was non-representative as participants were sourced from DI support networks, although it obviously suggests some DI adults have had negative experiences and feel the need for support (reviewed in Lycett et al., 2005).

xii These insights into infertility counselling procedures were provided during interviews with fertility counsellors employed by two major fertility clinics. Their names have been changed to preserve confidentiality.

xiii While, to my knowledge, no such services are currently operating in New Zealand, they have emerged in other contexts where a decline in the number of sperm donors is fuelling demand among single women and lesbian couples in particular. Such services include UK-based "SpermDirect" and "Man Not Included". The latter was recently exposed for various policy breaches, including inadequate screening of donors, failure to preserve donor anonymity, and multiple uses of the same donor (Nixson and Knowsley, 2004).

xiv New Zealand fertility clinics routinely screen for Syphilis, Hepatitis B and C, Chlamydia, and HIV, and most require sperm donors to complete a lifestyle declaration form similar to that used by blood donors, which aims to identify those with increased risk of HIV exposure. Sperm is also quarantined for 6 months after the last donation, reflecting the generally accepted 6-month 'window' for the onset of HIV infection. While these measures cannot entirely rule out the transmission of STDs including HIV, they do make such transmission highly unlikely. For these reasons, using donor sperm obtained via a registered clinic is clearly a 'safer' option than using unscreened sperm obtained via informal means, and this is a large part of the reason why a growing number of single women and lesbian couples actively seek to use screened sperm. These clear medical benefits must obviously be weighed up against the more intrusive aspects of using sperm obtained from a registered clinic, including the 
now mandatory requirement for donors to be identifiable, and the recording of extensive personal information.

${ }^{\mathrm{xv}}$ Lead by the Destiny Church, conservative Christians have become increasingly political active over the past five years, expressing virulent opposition to the Civil Unions Bill 2004, which extends many of the same legal rights and protections of marriage to de facto and gay partnerships, and related changes to the Care of Children Bill 2004 and Status of Children Amendment Act 2004 to legally recognise same-sex parents. 